\title{
Lipid, sterols and fatty acids of abyssal polychaetes, crustaceans, and a cnidarian from the northeast Pacific Ocean: food web implications
}

\author{
Jeffrey C. Drazen ${ }^{1, *}$, Charles F. Phleger ${ }^{2,3}$, Michaela A. Guest ${ }^{4}$, \\ Peter D. Nichols ${ }^{2,3}$ \\ ${ }^{1}$ University of Hawaii, Department of Oceanography, 1000 Pope Road, Honolulu, Hawaii 96822, USA
${ }^{2}$ CSIRO, Marine and Atmospheric Research, Food Futures Flagship, Hobart, Tasmania 7000, Australia
${ }^{3}$ Antarctic and Climate Ecosystems CRC, Hobart, Tasmania 7001, Australia
${ }^{4}$ Tasmanian Aquaculture and Fisheries Institute, Taroona, Nubeena Crescent, Tasmania 7053, Australia
}

ABSTRACT: The lipid, sterol, and fatty acid compositions of the abyssal anemone Bathyphellia australis, the 3 polychaetes Laetmonice sp., Paradiopatra sp. and Travisia sp., 3 crustaceans (Munidopsis sp. and 2 lysianassid amphipods), and an unidentified caridean shrimp were determined from a site in the northeast Pacific Ocean. Lipid composition was dominated by phospholipids in most species. However, energy storage lipids (triacylglycerols and wax esters) contributed $>50 \%$ to the total lipids in the lysianassid amphipods and the unidentified caridean shrimp, and lipids made up 19 and $45 \%$ of amphipod and $14 \%$ of shrimp dry mass, suggesting sporadic feeding and the need for energy storage. The dominant sterol was cholesterol. The presence of phytosterols in the anemone, the polychaetes and Munidopsis sp. suggested consumption of phytodetritus, but none of the specimens had levels suggesting that phytodetritus was their main food resource. The levels of essential photosynthetically derived polyunsaturated fatty acids (PUFA) corroborated the sterol results. The ratio of 18:1 $\omega 9 / 18: 1 \omega 7$ further suggested carnivory as the predominant mode of foraging in the abyssal animals, although to varying degrees. Some distinct differences in the fatty acid (FA) composition of these animals allowed for their separation, confirming that FA profiles will be useful in future biomarker approaches to deep-sea food web studies.

KEY WORDS: Polychaeta · Cnidaria · Crustacea · Deep sea · Trophic biology · Lipid composition · Sterols · Fatty acid biomarkers

\section{INTRODUCTION}

The benthic megafauna are important members of abyssal communities. Echinoderms typically dominate (Billett 1991, Ruhl 2007), while polychaetes, crustaceans, and anemones are also common and often abundant (Lauerman et al. 1996). The trophic relationships of these animals are poorly understood and are often based on functional morphology or assumptions derived from knowledge of shallow water members of the groups. This lack of information has hampered understanding of deep-sea food web function and basic ecological relationships. Studies have identified broad feeding guilds
(Fauchald \& Jumars 1979) and more detailed niche separation between related species (Cartes et al. 2007). In general, polychaetes and crustaceans can be consumers of surface-derived phytodetrital material, predators on other abyssal fauna, or scavengers on carrion. Anemones are less studied, but the consumption of detritus and benthopelagic plankton are obvious feeding modalities. All these abyssal megafauna are also potential prey for higher trophic levels such as fishes (Martin \& Christiansen 1997, Drazen et al. 2008a). Thus, polychaetes, crustaceans, and anemones play an important and diverse role in deep-sea food webs and more information on their trophic relationships would be helpful. 
Lipid biomarkers are useful tools for studying trophic ecology and determining food web connections. The relative percentage of lipid classes helps to characterize the trophic status of an organism. Triacylglycerols (TAG) are short-term energy storage lipids, whereas wax esters (WE) are long-term energy storage lipids. During starvation stress, TAG are utilized before WE (Lee \& Patton 1989). Phospholipids (PL) and sterols (ST) are primarily membrane structural components, and dominance of these lipid classes in the lipid profile indicates a constant food source. Cholesterol is the main ST in most animals, and the presence of other ST may provide good trophic indicators. For example, phytosterols are synthesized by algae and plants. Their main function is to regulate membrane fluidity (Rozner \& Garti 2006). They are structurally similar to cholesterol, although they have an extra hydrophobic carbon chain at the C-24 position. 24-Ethylcholesterol is the major phytosterol in land plants (Trautwein et al. 2003) and may be abundant in select marine phytoplankton (Volkman 1986). Organisms can have unique fatty acid (FA) profiles that can be traceable, and many of these FA are transferred from prey to predator without modification (Nichols et al. 1986, Phleger et al. 1998). FA have been used as dietary tracers in the ocean since the 1960s (Ackman \& Eaton 1966, Sargent 1976) to explore dietary relationships in a number of diverse marine organisms (Nichols et al. 2007). The approach is based on the assumption that many FA in the ocean, particularly polyunsaturated FA (PUFA), can only be biosynthesized by certain phytoplankton and macroalgal species and become essential dietary components to higher trophic levels. Phytoplankton and macroalgae are often characterized by very distinct ratios of FA, and these ratios influence the FA profiles of higher organisms, thus making them useful tools for providing information on food webs (Graeve et al. 2002).

Few studies have employed lipid and FA profiles to study feeding ecology and food webs in the deep sea. Studies of hydrothermal vent ecosystems showed a strong bacterial dietary input for all vent invertebrates, while archaeal-derived ether lipids were not detected (Phleger et al. 2005a,b). Signature lipid studies of abyssal zooplankton in the Atlantic have helped to identify specific feeding niches and have suggested ties between bentho-pelagic copepods and phytodetrital food sources even at great depths (Bühring \& Christiansen 2001). However, no studies have yet used lipid biomarker techniques to study abyssal megafauna in the Pacific, other than echinoderms (Drazen et al. 2008b).

In this study, the lipid, FA and ST composition of 3 polychaetes, 4 crustaceans, and an anemone from a site in the abyssal northeast Pacific Ocean were analysed. Recent studies at this site indicate interannual fluctuations in abundance of the benthic megafauna related to changes in the productivity of overlying surface waters (Ruhl \& Smith 2004). The goal of the present study was to assess their feeding habits, using lipid biomarkers, and also to ascertain their lipid profiles for use in a larger study incorporating diet analysis and stable isotope signatures to examine food web dynamics and trophic ecology of top predators in the ecosystem (Drazen et al. 2008a).

\section{MATERIALS AND METHODS}

Sampling. All samples were taken during a research cruise on the RV 'Atlantis' to Stn $\mathrm{M}\left(34^{\circ} 50^{\prime} \mathrm{N}, 123^{\circ} 0^{\prime} \mathrm{W}\right.$, $4100 \mathrm{~m}$ water depth) in the northeast Pacific, $220 \mathrm{~km}$ west of Point Conception, California, during August 2006. For a complete description of the physical and biological attributes of this station, see Smith \& Druffel (1998). In brief, this site is on the Monterey Abyssal Fan and lies underneath the California Current. The bottom is flat with sediments composed of fine silt and clay. Particulate matter fluxes to the seafloor show a distinct seasonal cycle, following the cycle in surface water productivity, with a peak in summer months. August of 2006 showed the peak seasonal flux for the year at $10.26 \mathrm{mg} \mathrm{C} \mathrm{m}^{-2} \mathrm{~d}^{-1}$.

Common cnidarian, polychaete and crustacean species, as determined from previous camera sled and trawl analyses (Lauerman et al. 1996), were sampled. Collections of specimens were made during DSV 'Alvin' dives using scoops and a suction sampler and returned to the surface in plastic sample boxes. Specimens were also collected using a $12.3 \mathrm{~m}$ otter trawl deployed from the RV 'Atlantis'. In this case, only specimens in very good condition, showing little or no signs of damage, were used. Specimens were rinsed free of any adhering sediment before tissues were sampled. These included Paradiopatra sp., Laetmonice sp. and Munidoposis sp. Two unidentified species of lysianassid amphipods (given here simply as A and B) were collected using a baited trap. Abdominal muscle tissue of the large galatheid crab Munidopsis sp. was sampled. A caridean shrimp was split longitudinally and one-half was used for the signature lipid analysis described below, while the other was used for a different study. The lysianassid amphipods were small (2 to $6 \mathrm{~mm}$ ), so 7 to 8 individuals were pooled for each sample. The rest of the invertebrates were whole specimens. All samples were frozen and stored in cryovials under liquid nitrogen on board ship and subsequently stored at $-80^{\circ} \mathrm{C}$ in the laboratory. Samples were freeze-dried, ground and then shipped to CSIRO Marine and Atmospheric Research, Hobart, Tasmania, 
Australia, for lipid analyses. Freeze-dried sample weights were between 0.02 and $0.39 \mathrm{~g}$.

Lipid extraction. Samples were quantitatively extracted overnight using a modified Bligh \& Dyer (1959) one-phase methanol:chloroform:water (2:1:0.8 v:v:v) extraction. The phases were separated by the addition of chloroform-water (final solvent ratio 1:1:0.9 v:v:v methanol:chloroform:water). The total solvent extract (TSE) was concentrated using rotary evaporation at $40^{\circ} \mathrm{C}$.

Lipid classes. An aliquot of the TSE was analysed using an Iatroscan MK V TH10 thin-layer chromatography-flame ionization detector (TLC-FID) analyser to quantify individual lipid classes (Volkman \& Nichols 1991). Samples were applied in duplicate to silica gel SIII chromarods (5 $\mu \mathrm{m}$ particle size) using $1 \mu l$ micropipettes. Chromarods were developed in a glass tank lined with pre-extracted filter paper. The primary solvent system used for the lipid separation was hexane-diethyl ether-acetic acid (60:17:0.1), a mobile phase resolving non-polar compounds such as WE, TAG, free fatty acids (FFA) and ST from PL. A second non-polar solvent system of hexane-diethyl ether (96:4) was used to resolve hydrocarbons, WE, TAG, and diacylglycerol ether (DAGE). After development, the chromarods were oven-dried and analysed immediately to minimize absorption of atmospheric contaminants. The FID was calibrated for lipid class (phosphatidylcholine, cholesterol, cholesteryl oleate, oleic acid, squalene, TAG derived from fish oil, WE derived from orange roughy Hoplostethus atlanticus oil, and DAGE derived from shark liver oil; 0.1 to $10 \mu \mathrm{g}$ range). Peaks were quantified on an IBMcompatible computer using DAPA Scientific software (Kalamunda). TLC-FID results are generally reproducible to $\pm 10 \%$ of individual lipid class abundances (Volkman \& Nichols 1991).

Fatty acids. An aliquot of the TSE was transmethylated to produce fatty acid methyl esters (FAME) using methanol:chloroform:concentrated hydrochloric acid $\left(10: 1: 1,80^{\circ} \mathrm{C}, 2 \mathrm{~h}\right)$ (Christie 1982). FAME were extracted into hexane:chloroform $(4: 1,3 \times 1.5 \mathrm{ml})$. FAME were treated with N,O-bis-(trimethylsilyl)-trifluoroacetamide (BSTFA $50 \mu \mathrm{l}, 60^{\circ} \mathrm{C}$, overnight) to convert $\mathrm{ST}$, alcohols, and hydroxyl FA to their corresponding trimethylsilyl (TMSi) ethers.

Gas chromatographic (GC) analyses were performed with an Agilent Technologies 6890N GC (Palo Alto) equipped with an HP-5 cross-linked methyl silicone fused silica capillary column $(50 \mathrm{~m} \times 0.32 \mathrm{~mm}$ inner diameter), an FID, a split/splitless injector and an Agilent Technologies 7683 Series auto sampler and injector. Helium was the carrier gas. Following the addition of methyl nonodecanoate internal injection standard, samples were injected in splitless mode at an oven temperature of $50^{\circ} \mathrm{C}$. After $1 \mathrm{~min}$, the oven temperature was raised to $150^{\circ} \mathrm{C}$ at $30^{\circ} \mathrm{C} \mathrm{min}^{-1}$, then to $250^{\circ} \mathrm{C}$ at $2^{\circ} \mathrm{C} \mathrm{min}{ }^{-1}$ and finally to $300^{\circ} \mathrm{C}$ at $5^{\circ} \mathrm{C} \mathrm{min}^{-1}$. Peaks were quantified with Agilent Technologies GC ChemStation software. Individual components were identified using mass spectral data and by comparing retention time with data obtained for authentic and laboratory standards. GC results are subject to an error of $\pm 5 \%$ of the individual component area. GC-mass spectrometric (GC-MS) analyses were performed on a Finnigan Thermoquest GCQ GC-MS fitted with an oncolumn injector using the software Xcalibur (Thermoquest). The GC was fitted with a capillary column similar to that described above.

Statistical analysis. FA profiles of different taxa were compared using Principal Component Analysis (PCA). PCA reduces the number of dimensions produced by the large number of variables and uses linear correlations (components) to identify those FA that contribute most to the separation between observed groups (Best et al. 2003). FA that contributed a mean of less than $1.0 \%$ (of total FA) to the profile were omitted from statistical analyses. All analyses were performed on \% composition data and results were confirmed by analysis of $\mathrm{mg} \mathrm{g}^{-1}$ fatty acid data (data not shown). Multivariate statistical analyses were performed using PRIMER 6 software (PRIMER-E).

\section{RESULTS}

\section{Lipid content and classes}

Total lipid content varied between the animals examined (Table 1). Lipid content was low (ca. 3 to $5 \%$ ) in the 2 large polychaetes, Laetmonice sp. (Aphroditidae) and Travisia sp. (Opheliidae), the anemone Bathyphellia australis, and the galatheid crab Munidopsis sp. The onuphid polychaete Paradiopatra sp. and an unidentified caridean shrimp contained more lipid and the 2 lysianassid amphipods contained the most lipid as a proportion of dry weight (18.6 to $44.9 \%$ ).

Lipid classes were dominated by PL in all organisms, except the shrimp and amphipods (Table 1). Storage lipids (TAG and WE) in polychaetes were generally low, although Paradiopatra sp., the species with the highest lipid content of all the polychaetes, had $11 \%$ WE. The shrimp and amphipods contained high amounts of storage lipids (39 to $83 \%$ TAG), but Munidopsis sp. did not. This probably reflects the fact that only Munidopsis sp. abdominal muscle was analysed, while for the other species total mass was extracted. In the crustacean Jasus edwardsii, the lipid class (and FA) profiles of leg and tail tissues were generally very similar, while those in the hepatopancreas differed 
Table 1. Lipid content and composition of abyssal Cnidaria, Polychaeta, and Crustacea. n: number of samples, HC: hydrocarbon, WE: wax ester, DAGE: diacylgylceryl ether, TAG: triacylgylcerol, FFA: free fatty acid, ST: sterol, PL: phospholipid. Means \pm SD

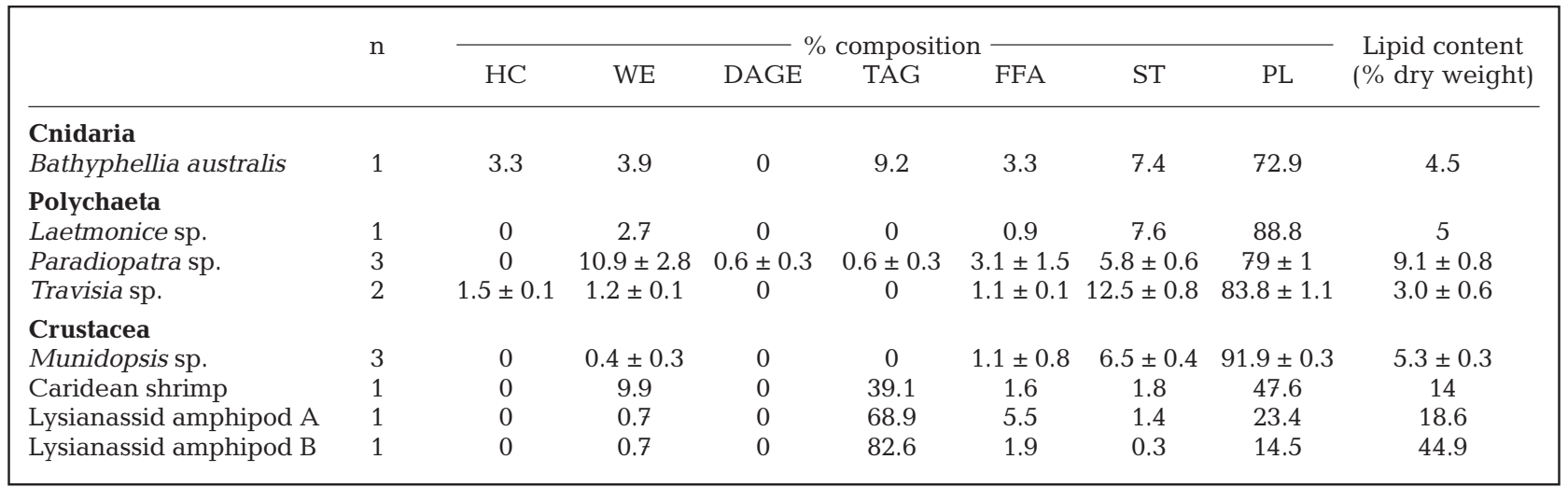

(Nelson et al. 2005). It is likely that storage lipids could be found in the hepatopancreas of Munidopsis sp. since this is often a lipid-rich tissue in crustaceans (Nelson et al. 2005). The FA of Munidopsis sp. were also primarily from PL, while in the other crustaceans, the FA reported were from both storage lipid and PL. ST in the animals generally ranged from 5 to $12 \%$, but was considerably lower in the TAG-rich amphipods and shrimp (Table 1). FFA was generally low in all samples.

\section{Sterols}

The ST composition of the different taxa were dominated by cholesterol ( 73 to $99 \%$, as \% total ST), while the smaller amounts of other sterols varied in proportion intraspecifically (Table 2). In the polychaetes, smaller proportions of trans-22-dehydrocholesterol, dihydrobrassicasterol, brassicasterol, sitosterol, and 24methylenecholesterol were found. ST composition in Bathyphellia australis was similar to that of the polychaetes. ST in crustaceans were less diverse than in the other taxa, with only cholesterol found in lysianassid amphipod B (Table 2). While the ST composition of Munidopsis sp. was less diverse than that of the other animals, it was much more diverse than either that of the shrimp or of the amphipods, including the presence of several unidentified ST (as 'other' in Table 2). Similar to the shrimp, Munidopsis sp. had low levels of trans-22-dehydrocholesterol and trans-22-dehydrocholestanol with smaller amounts of a few other ST. Total stanols were low in all of the species examined (0 to $5 \%$ ), but total phytosterols ranged greatly from $0 \%$ in the caridean shrimp and lysianassid amphipod B to $16.4 \%$ in Travisia sp. (Table 2).

Table 2. Sterol composition (of total sterols) of abyssal Cnidaria, Polychaeta, and Crustacea. Means \pm SD

\begin{tabular}{|c|c|c|c|c|c|c|c|c|}
\hline \multirow[t]{2}{*}{ Sterol } & \multirow{2}{*}{$\begin{array}{l}\text { - Cnidaria - } \\
\text { Bathyphellia } \\
\text { australis }\end{array}$} & \multicolumn{3}{|c|}{ Polychaeta } & \multirow[b]{2}{*}{$\begin{array}{l}\text { Muni- } \\
\text { dopsis } \\
\text { sp. }\end{array}$} & \multicolumn{2}{|c|}{ Crustacea } & \multirow{2}{*}{$\begin{array}{l}\text { Lysianassid } \\
\text { amphipod } \\
\text { B }\end{array}$} \\
\hline & & $\begin{array}{c}\text { Laetmonice } \\
\text { sp. }\end{array}$ & $\begin{array}{l}\text { Para- } \\
\text { diopatra } \\
\text { sp. }\end{array}$ & $\begin{array}{l}\text { Travisia } \\
\text { sp. }\end{array}$ & & $\begin{array}{l}\text { Caridean } \\
\text { shrimp }\end{array}$ & $\begin{array}{c}\text { Lysianassid } \\
\text { amphipod } \\
\text { A }\end{array}$ & \\
\hline 24-nordehydrocholesterol & 1.1 & 0.0 & $0.2 \pm 0.2$ & $1.2 \pm 0.1$ & $0 \pm 0$ & 0.0 & 0.0 & 0.0 \\
\hline Cis-22-dehydrocholesterol/occelasterol & 1.5 & 0.2 & $1 \pm 0.1$ & $0.5 \pm 0.1$ & $0 \pm 0$ & 0.0 & 0.0 & 0.0 \\
\hline Trans-22-dehydrocholesterol & 8.6 & 3.2 & $6.7 \pm 0.2$ & $5.2 \pm 0.7$ & $3.8 \pm 0.5$ & 3.2 & 0.0 & 0.0 \\
\hline Trans-22-dehydrocholestanol & 1.5 & 1.5 & $1.5 \pm 0.2$ & $2.1 \pm 0.1$ & $1.8 \pm 0.1$ & 0.0 & 1.8 & 0.0 \\
\hline Cholesterol & 73.2 & 88.2 & $78.5 \pm 1.7$ & $72.9 \pm 0.7$ & $82.2 \pm 1.7$ & 96.8 & 98.2 & 100 \\
\hline Cholestanol & 0.8 & 0.5 & $1.4 \pm 0.1$ & $0.4 \pm 0.2$ & $0.1 \pm 0.2$ & 0.0 & 0.0 & 0.0 \\
\hline Brassicasterol/crinosterol & 3.3 & 2.1 & $2.8 \pm 0.3$ & $2.6 \pm 0.4$ & $0 \pm 0$ & 0.0 & 0.0 & 0.0 \\
\hline Brassicastanol/crinostanol & 0.0 & 0.0 & $0 \pm 0$ & $2.5 \pm 0.2$ & $0 \pm 0$ & 0.0 & 0.0 & 0.0 \\
\hline 24-methylenecholesterol & 3.0 & 0.5 & $0.5 \pm 0.5$ & $0.6 \pm 0$ & $0 \pm 0$ & 0.0 & 0.0 & 0.0 \\
\hline Campesterol/dihydrobrassicasterol & 2.1 & 2.7 & $2.8 \pm 0.4$ & $6 \pm 0.4$ & $0.3 \pm 0.1$ & 0.0 & 0.0 & 0.0 \\
\hline 23,24 -dimethylcholesta-5, 22E-dien-3 $\beta$-ol & 0.0 & 0.4 & $0 \pm 0$ & $0.6 \pm 0.1$ & $0.2 \pm 0.1$ & 0.0 & 0.0 & 0.0 \\
\hline Stigmasterol/poriferasterol & 0.0 & 0.0 & $0.3 \pm 0.3$ & $0.5 \pm 0$ & $0 \pm 0$ & 0.0 & 0.0 & 0.0 \\
\hline 23,24-dimethylcholesta-5-en-3 $\beta$-ol & 0.0 & 0.0 & $0 \pm 0$ & $0 \pm 0$ & $0.3 \pm 0.3$ & 0.0 & 0.0 & 0.0 \\
\hline Sitosterol/clionosterol & 1.4 & 0.5 & $3.7 \pm 0.3$ & $4.2 \pm 0.7$ & $0.3 \pm 0.2$ & 0.0 & 0.0 & 0.0 \\
\hline Other & 3.4 & 0.2 & $0.6 \pm 0.1$ & $0.7 \pm 0.5$ & $11.1 \pm 1.3$ & 0.0 & 0.0 & 0.0 \\
\hline Total stanols & 2.3 & 2.0 & $2.9 \pm 0$ & $5 \pm 0.2$ & $1.9 \pm 0.3$ & 0.0 & 1.8 & 0.0 \\
\hline Total phytosterols & 6.8 & 5.7 & $9.6 \pm 1$ & $16.4 \pm 0.7$ & $1 \pm 0.4$ & 0.0 & 0.0 & 0.0 \\
\hline
\end{tabular}




\section{Fatty acids}

The total proportions of PUFA and its composition varied between the species. Total PUFA were lower in the polychaete Travisia sp., compared to Laetmonice sp. and Paradiopatra sp. (Fig. 1). Total PUFA were highest in the anemone Bathyphellia australis and the galatheid crab Munidopsis sp. (40\%). In contrast, the caridean shrimp and the 2 lysianassid amphipods had the lowest PUFA levels (12 to $20 \%$ ). Much of the total PUFA difference is reflected in the amounts of eicosapentaenoic acid (EPA; 20:5 13 ), arachidonic acid (AA;

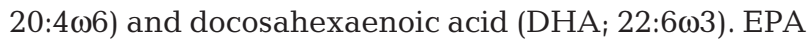
levels were highest in Munidopsis sp. and lowest in Travisia sp. (Table 3). AA levels were mostly much lower than EPA and less variable interspecifically. DHA content was highest in B. australis and Munidopsis sp., lower in Laetmonice sp., Paradiopatra sp., the caridean shrimp and the lysiannassid amphipods, and lowest in Travisia sp. Paradiopatra sp. had much higher 22:2NMI (nonmethylene-interrupted diunsaturated FA) than the other polychaetes, and only small amounts were detected in most other animals. Although Travisia sp. had low total amounts of PUFA, it had moderate amounts of C21 PUFA, and 20:2NMI proportions were higher than in other animals.

Monounsaturated fatty acids (MUFA) were the most abundant type of FA and were fairly consistent in total proportions in the anemone, the polychaetes and Munidopsis sp. (37 to $47 \%$ ); however, the caridean shrimp and lysianassid amphipods had higher levels (ca. 61\%; Fig 1). MUFA composition differed among these 3 crustaceans and among the other taxa. The lysianassid amphipods contained high proportions of 18:1 $\omega 9$, whereas the other 2 crustaceans had about half as much

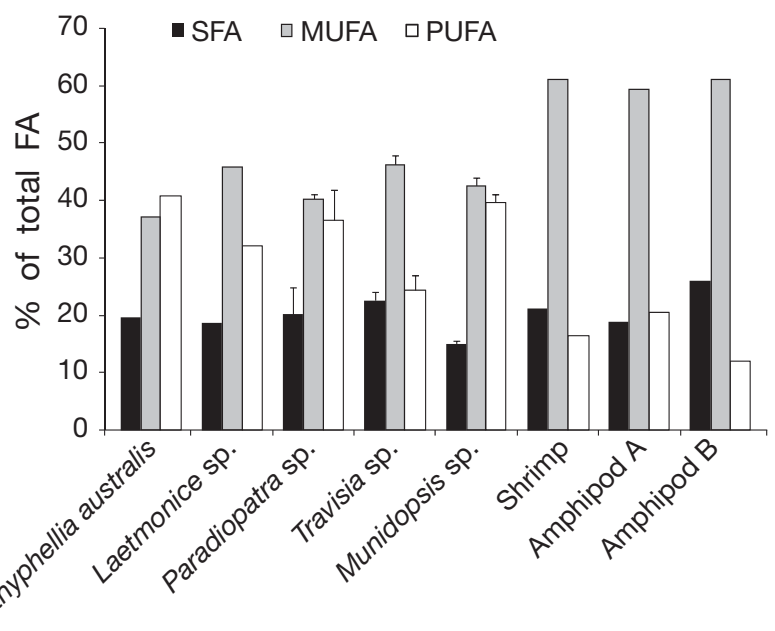

Fig. 1. Fatty acid composition by group for abyssal anemone, polychaetes and crustaceans. FA: fatty acids; SFA: saturated fatty acids; MUFA: monosaturated fatty acids; PUFA: polysaturated fatty acids. Values are means $\pm \mathrm{SD}$
(Table 3) and the other taxa even less. The shrimp, on the other hand, had larger proportions of $16: 1 \omega 7 \mathrm{C}$ and 20:1 $17 \mathrm{C}$ compared to the amphipods or other species.

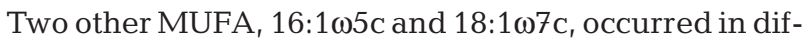
ferent proportions among taxa (Table 3). C20 MUFA proportions were different both within and between the crustaceans and polychaetes (Table 3).

Total saturated fatty acids (SFA) were similar in most taxa (Fig. 1). Major SFA included 16:0 and 18:0 (Table 2). Total SFA were lower in Munidopsis sp. (Fig. 1) than other taxa. In comparison to the other crustaceans, Munidopsis sp. had lower levels of 16:0. The amphipods had small but slightly higher proportions of 14:0 compared to the other taxa.

Differences in FA profiles among taxa were clearly separated by the PCA (Fig. 2). FA contributing the most to the separation of groups along PC1 were

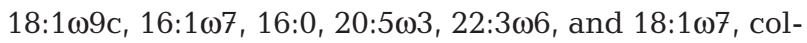
lectively explaining $49 \%$ of total variance. The amphipods were most clearly distinguished from other taxa along this axis, and shrimp from polychaetes and Bathyphellia australis. Major FA contributing to PC2 were $20: 5 \omega 3,22: 6 \omega 3,18: 1 \omega 7 \mathrm{c}, 20: 1 \omega 7 \mathrm{c}, 20: 2 \mathrm{NMI}$, and $22: 4 \omega 3$, explaining $28 \%$ of the total variance. This axis clearly separated Munidopsis sp. and Travisia sp. from the rest of the taxa.

\section{DISCUSSION}

\section{Polychaeta}

Lipid content can provide an insight into the tempo of feeding. For instance, polychaetes from hydrothermal vent environments have large proportions of membrane structural lipids such as PL and ST and low amounts of energy storage lipids such as TAG and WE, which is indicative of their relatively constant food source (Phleger et al. 2005b). Storage lipid content was also low in the 2 large polychaetes Laetmonice sp. (Aphroditidae) and Travisia sp. (Opheliidae) in our study (Table 1). Paradiopatra sp. contained $12 \%$ storage lipids, which may indicate a more sporadic diet. Paradiopatra sp. is an onuphid polychaete that lives in a mud tube which protrudes from the sediment and then curves back down towards it (Lauerman et al. 1996). Onuphids are opportunistic feeders that consume detritus and prey on other fauna (Fauchald \& Jumars 1979). With a sessile lifestyle, Paradiopatra sp. relies on food coming to it, which perhaps necessitates greater energy stores. However, with only modest proportions of energy storage lipids, the case is not nearly as clear as for the crustaceans (see below). Reproductive events could also be influencing lipid storage and composition. 
Table 3. Fatty acid composition of abyssal Cnidaria, Polychaeta and Crustacea. Ratios are in bold. Means \pm SD

\begin{tabular}{|c|c|c|c|c|c|c|c|c|}
\hline \multirow{2}{*}{$\begin{array}{l}\text { Fatty acids } \\
\text { and ratios }\end{array}$} & \multirow{2}{*}{$\begin{array}{c}\text { - Cnidaria- }- \\
\text { Bathyphellia } \\
\text { australis }\end{array}$} & \multirow{2}{*}{$\begin{array}{l}\text { Laetmonice } \\
\text { sp. }\end{array}$} & \multirow{2}{*}{$\begin{array}{c}\text { - Polychaeta } \\
\text { Paradiopatra } \\
\text { sp. }\end{array}$} & \multirow[b]{2}{*}{$\begin{array}{l}\text { Travisia } \\
\text { sp. }\end{array}$} & \multirow[b]{2}{*}{$\begin{array}{l}\text { Munidopsis } \\
\text { sp. }\end{array}$} & \multirow{2}{*}{$\begin{array}{l}\text { Crust } \\
\text { Caridean } \\
\text { shrimp }\end{array}$} & \multirow{2}{*}{$\begin{array}{l}\text { Lysianassid } \\
\text { amphipod A }\end{array}$} & \multirow[b]{2}{*}{$\begin{array}{l}\text { Lysianassid } \\
\text { amphipod B }\end{array}$} \\
\hline & & & & & & & & \\
\hline 14:0 & 0.1 & 0.6 & $0.7 \pm 0.6$ & $1.2 \pm 0$ & $0.5 \pm 0.1$ & 0.4 & 1.3 & 1.8 \\
\hline a15:0 & 0.0 & 0.1 & $0 \pm 0$ & $1.2 \pm 0.1$ & $0.1 \pm 0$ & 0.2 & 0 & 0 \\
\hline $15: 0$ & 0.4 & 0.4 & $0.3 \pm 0.1$ & $0.5 \pm 0$ & $0.5 \pm 0.1$ & 0.3 & 0.4 & 0.3 \\
\hline i16:0 & 0.6 & 0.2 & $0.2 \pm 0$ & $0.4 \pm 0$ & $0.1 \pm 0$ & 0.4 & 0.1 & 0.1 \\
\hline $16: 0$ & 9.7 & 7.8 & $9.1 \pm 4$ & $9.4 \pm 1.3$ & $7.6 \pm 0.8$ & 12.4 & 13.2 & 16.5 \\
\hline $16: 1+16: 2$ & 0.7 & 0.0 & $0 \pm 0$ & $0 \pm 0$ & $0 \pm 0$ & 0.0 & 0 & 0 \\
\hline $16: 1 \omega 5 c$ & 0.4 & 0.7 & $0.2 \pm 0$ & $3.8 \pm 0.5$ & $0.2 \pm 0$ & 0.8 & 0.2 & 0.1 \\
\hline $16: 1 \omega 7 \mathrm{C}$ & 1.5 & 3.6 & $3.3 \pm 1.2$ & $2.6 \pm 0.6$ & $5.3 \pm 1.5$ & 18.1 & 8.5 & 15.0 \\
\hline $16: 1 \omega 9 c$ & 0.5 & 0.6 & $0.1 \pm 0.1$ & $0.4 \pm 0.4$ & $0.3 \pm 0.1$ & 0.9 & 0.8 & 0.4 \\
\hline i17:0 & 1.4 & 0.4 & $1.9 \pm 0.3$ & $0.4 \pm 0.1$ & $0.5 \pm 0.1$ & 0.8 & 0.2 & 0.1 \\
\hline a17:0 & 1.5 & 0.9 & $0.4 \pm 0$ & $1.6 \pm 0.2$ & $0.4 \pm 0$ & 1.8 & 0.2 & 0.1 \\
\hline $17: 0$ & 1.8 & 1.3 & $1.3 \pm 0.2$ & $0.8 \pm 0$ & $0.6 \pm 0.1$ & 0.7 & 0.4 & 0.7 \\
\hline $17: 1 \omega 6 c$ & 0.2 & 0.2 & $0.1 \pm 0$ & $1.8 \pm 0.2$ & $0.2 \pm 0$ & 0.2 & 0.1 & 0 \\
\hline $17: 1 \omega 8 c$ & 1.0 & 0.6 & $0.4 \pm 0$ & $0.7 \pm 0.1$ & $1 \pm 0.2$ & 0.8 & 0.8 & 1.1 \\
\hline $18: 0$ & 3.2 & 5.4 & $5.1 \pm 0.4$ & $5.2 \pm 0$ & $3.2 \pm 0.1$ & 2.8 & 2.3 & 3.2 \\
\hline $18: 1 \omega 5 c$ & 1.8 & 1.7 & $0.2 \pm 0$ & $1.7 \pm 0.2$ & $1 \pm 0.2$ & 1.6 & 0.3 & 0.4 \\
\hline $18: 1 \omega 7 \mathrm{C}$ & 5.5 & 5.8 & $8.6 \pm 1.4$ & $7.6 \pm 0.4$ & $13.9 \pm 0.7$ & 8.6 & 4.2 & 3.7 \\
\hline $18: 1 \omega 9 c+18: 3 \omega 3$ & 9.3 & 5.9 & $6.6 \pm 5.2$ & $6.3 \pm 0.5$ & $14.2 \pm 0.2$ & 14.0 & 35.9 & 35.2 \\
\hline $18: 2 \omega 6$ & 0.4 & 1.9 & $0.3 \pm 0.1$ & $1.2 \pm 0$ & $0.6 \pm 0.2$ & 0.7 & 1.5 & 1.8 \\
\hline 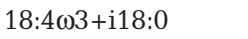 & 1.1 & 0.3 & $0.9 \pm 0.2$ & $0 \pm 0$ & $1.5 \pm 0.5$ & 0.2 & 0.6 & 0.6 \\
\hline a19:0+19:1 & 0.2 & 0.6 & $0.2 \pm 0$ & $0.9 \pm 0$ & $0.4 \pm 0$ & 0.6 & 0.3 & 0.1 \\
\hline $19: 1 b$ & 1.2 & 2.6 & $2.4 \pm 0.4$ & $4.5 \pm 0.3$ & $1.1 \pm 0.2$ & 0.8 & 0.2 & 0.1 \\
\hline $20: 0$ & 0.2 & 0.5 & $0.5 \pm 0$ & $0.4 \pm 0$ & $0.2 \pm 0.1$ & 0.2 & 0 & 1.9 \\
\hline $20: 1$ & 0.2 & 0.4 & $0.3 \pm 0$ & $0.2 \pm 0$ & $0.1 \pm 0$ & 0.6 & 0.1 & 0.1 \\
\hline $20: 1 \omega 7 c$ & 7.7 & 6.4 & $4.6 \pm 0.7$ & $2.7 \pm 0.2$ & $0.3 \pm 0.1$ & 8.5 & 0.8 & 0.3 \\
\hline $20: 1 \omega 9 c$ & 2.0 & 0.0 & $9.4 \pm 1.1$ & $0 \pm 0$ & $1 \pm 0.2$ & 0.0 & 2.9 & 1.6 \\
\hline $20: 1 \omega 11 c$ & 0.0 & 11.8 & $0.4 \pm 0.3$ & $11.2 \pm 0.7$ & $0.5 \pm 0.2$ & 4.3 & 1.2 & 1.3 \\
\hline 20:2NMI & 0.3 & 2.5 & $0.8 \pm 0$ & $5.5 \pm 0.1$ & $0.2 \pm 0$ & 0.8 & 0 & 0 \\
\hline $20: 2 \omega 6$ & 1.2 & 0.9 & $0.7 \pm 0.2$ & $0 \pm 0$ & $1.1 \pm 0.1$ & 0.6 & 0 & 0 \\
\hline $20: 3 \omega 6$ & 0.0 & 0.9 & $0.3 \pm 0$ & $0 \pm 0$ & $0.2 \pm 0$ & 0.1 & 0.1 & 0.1 \\
\hline $20: 4 \omega 3$ & 0.2 & 0.0 & $0 \pm 0$ & $0.1 \pm 0.2$ & $0.2 \pm 0$ & 0.0 & 0.4 & 0.6 \\
\hline $20: 4 \omega 6$ AA & 3.1 & 0.2 & $1 \pm 0.2$ & $2.5 \pm 0.7$ & $4.1 \pm 0.5$ & 1.4 & 1.9 & 0.9 \\
\hline $20: 5 \omega 3$ EPA & 14.0 & 8.8 & $12.3 \pm 2.2$ & $2.2 \pm 0.4$ & $19.6 \pm 1.1$ & 7.2 & 6.3 & 2.7 \\
\hline $21: 1 \mathrm{a}$ & 0.0 & 0.6 & $0.4 \pm 0.1$ & $1.1 \pm 0.2$ & $0 \pm 0$ & 0.2 & 0 & 0 \\
\hline C21PUFA & 1.1 & 4.9 & $2.3 \pm 0.2$ & $8.4 \pm 0.6$ & $0.5 \pm 0.1$ & 0.7 & 0.1 & 0 \\
\hline $22: 1 \omega 7 \mathrm{C}$ & 0.5 & 3.2 & $0.3 \pm 0.1$ & $0.1 \pm 0.1$ & $1.1 \pm 0.1$ & 0.9 & 0.2 & 0 \\
\hline $22: 1 \omega 9 c+16: 0$ GED & 2.9 & 0.8 & $2.1 \pm 1.5$ & $0.8 \pm 0.1$ & $0.3 \pm 0.2$ & 0.4 & 1.1 & 0.3 \\
\hline $22: 1 \omega 11+13 c$ & 0.4 & 0.2 & $0 \pm 0$ & $0 \pm 0$ & $0 \pm 0$ & 0.0 & 0.8 & 0.7 \\
\hline 22:2NMIa ${ }^{\mathrm{a}}$ & 0.0 & 3.6 & $9.9 \pm 1.2$ & $2.1 \pm 0.1$ & $0 \pm 0$ & 0.2 & 0.1 & 0 \\
\hline 22:2NMIb ${ }^{b}$ & 0.5 & 1.6 & $2.5 \pm 0.4$ & $5.4 \pm 0.6$ & $0.1 \pm 0$ & 0.9 & 0.1 & 0.1 \\
\hline $22: 4 \omega 6$ & 2.0 & 0.8 & $0.8 \pm 0.2$ & $0.6 \pm 0.3$ & $0.2 \pm 0.2$ & 0.3 & 0.3 & 0.2 \\
\hline 22:5ஸ3 DPA(3) & 6.0 & 3.7 & $2.6 \pm 0.3$ & $1.3 \pm 0$ & $0.5 \pm 0.1$ & 0.8 & 1.4 & 1.4 \\
\hline 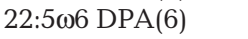 & 0.4 & 0.0 & $0.1 \pm 0.1$ & $0 \pm 0$ & $0.2 \pm 0$ & 0.1 & 0.2 & 0.2 \\
\hline 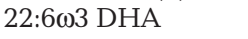 & 11.5 & 4.2 & $3.6 \pm 1$ & $0.2 \pm 0$ & $12.1 \pm 1.5$ & 3.3 & 7.9 & 3.7 \\
\hline $24: 1 b$ & 0.3 & 0.1 & $0.1 \pm 0.1$ & $0 \pm 0$ & $0.9 \pm 0.4$ & 0.0 & 0.5 & 0.1 \\
\hline other & 3.2 & 2.3 & $2.9 \pm 0.5$ & $3.1 \pm 0.3$ & $3.2 \pm 0.1$ & 1.7 & 2.0 & 2.2 \\
\hline 18:1 $\omega 9 / 18: 1 \omega 7$ & 1.7 & 1.0 & 0.8 & 0.8 & 1.0 & 1.6 & 8.4 & 9.4 \\
\hline
\end{tabular}

The ST compositions were dominated by cholesterol, which is the main ST in many animals, but variations that may indicate different feeding strategies were evident. Cholesterol is a major membrane component in worms and crustaceans, regulating membrane fluidity (Goad 1978, Okamura et al. 1985). High levels of cholesterol, such as those seen in this study, are suggestive of a carnivorous diet (Nelson et al.
2001), although polychaetes from hydrothermal vents consuming large amounts of microbial food have also been found to contain cholesterol (Phleger et al. 2005b). Trans-22-de-hydrocholesterol, the secondmost abundant ST (Table 2), is an intermediate in cholesterol synthesis, but it could also derive from animal food sources. Phytosterols were also present in the polychaetes, indicating a link to detrital food 


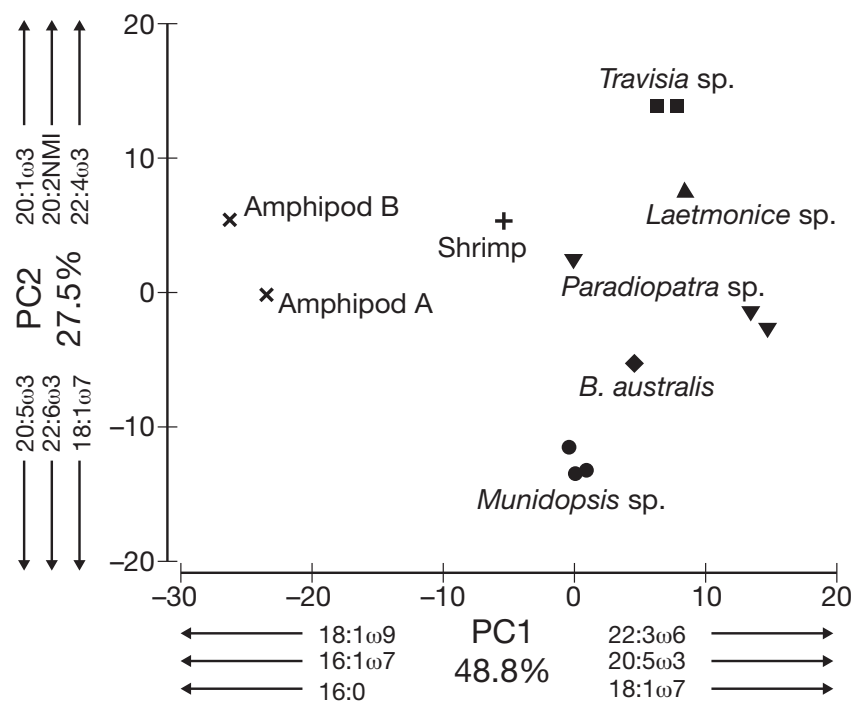

Fig. 2. First and second principal components derived from the fatty acid (FA) composition of Polychaeta (Laetmonice sp., Paradiopatra sp., and Travisia sp.), Cnidaria (Bathyphellia australis), and Crustacea (Munidopsis sp., caridean shrimp, and lysianassid amphipods A and B). PC1 explained $48.8 \%$ of the variability between FA profiles of the species examined. PC2 explained $27.5 \%$ of the variability. Arrows indicate FA contributing most to the distribution of species along each axis

sources. Sitosterol is the most abundant phytosterol in land plants (Trautwein et al. 2003); in the marine environment it is abundant in phytoplankton (Volkman 1986), and it is the most abundant phytosterol in some shallow water deposit feeding polychaetes (Judd 2001). The main phytosterols found in polychaetes in this study included sitosterol, brassicasterol and dihydrobrassicasterol. Amongst the polychaetes, Travisia sp. contained the highest proportions of phytosterols (Table 2), which reflects the subsurface deposit feeding nature of this burrowing ophelid (Fauchald \& Jumars 1979). Paradiopatra sp., which probably feeds on phytodetritus as described above, contained ca. $10 \%$ phytosterols, while the large predaceous Laetmonice sp. contained only $6 \%$. None of the polychaetes or other animals in the study appears to consume as much detritus as the almost exclusively deposit feeding holothurians and ophiuroids at this site, which contained from 31 to $70 \%$ phytosterols (Drazen et al. 2008b).

The FA compositions presented in Table 3 provide an initial basis for biomarker studies of abyssal food webs and give some insight into the diet of the examined taxa. Low FFA levels indicate little PL and TAG breakdown, low lipolytic and enzyme activity, and confirm the stability of samples during collection, transport and storage. The PUFA levels of the abyssal polychaetes suggest omnivory and links to the eupho- tic zone. Most animals cannot synthesize longer-chain PUFA, including EPA, DHA, and AA. Instead, these are formed by phytoplankton, some bacteria and heterotrophic protozoans, and are transferred through the food web. EPA is typically found in higher proportions in diatoms (Volkman et al. 1989), while flagellates contain higher DHA relative to EPA (Brown et al. 1993). Thus, high levels of these FA and the resulting high PUFA levels are suggestive of herbivory. For instance, the commensal deep-sea hydrothermal vent polychaete Amathys lutzi contained low amounts of PUFA with no EPA or DHA, indicating low reliance on photosynthetically produced material (Colaço et al. 2007). The pelagic polychaete Tomopteris carpenteri had higher total PUFA levels (59\% of total FA, with $28 \%$ DHA and $21 \%$ EPA) (Phleger et al. 1998) than the benthic polychaetes in this study. In contrast, another pelagic polychaete, Vanadis antarctica, had similar total PUFA, DHA, and EPA to the benthic polychaetes examined here (Fig. 1). V. antarctica may prey upon larval fish, whereas $T$. carpenteri has a more herbivorous diet, relying upon photosynthetically produced material (Phleger et al. 1998). Thus, the relatively low PUFA levels of polychaetes in this study suggest consumption of animal material as well as phytodetritus from surface waters. Travisia sp. had the lowest PUFA levels (Fig. 1) and had the greatest relative levels of phytosterols (Table 2), providing contrasting results. Ophelids, such as Travisia sp., are generally subsurface deposit feeders (Fauchald \& Jumars 1979). Subsurface detritus is usually reworked and more refractory than detritus settling to the seafloor. It might be depleted in PUFA, but not phytosterols. PUFA are rapidly degraded in sinking detritus (Wakeham et al. 1984), but whether their degradation is faster than ST is not known. Travisia sp. did have a different PUFA composition compared to the other polychaetes, which might reflect a different source of food but could also be the result of lipid metabolism.

MUFA composition provides further insight into trophodynamics, making it possible to distinguish between carnivory, herbivory and detritivory. The longchain MUFA, including the 20:1 isomers, were abundant in the polychaetes. Calanoid copepods have been reported as the major synthesizers of long-chain MUFA, including the 20:1 and 22:1 isomers, in marine food webs (Sargent \& Whittle 1981). However, 20:1 FA are rich in cold water Calanus spp. and are associated with their WE. Not all copepods are WE-rich and contain substantial 20:1 FA. Therefore, it is possible that the levels of 20:1 FA in the predatory polychaete Laetmonice sp. indicate the direct consumption of copepods. Copepod remains, including faecal pellets, are common components of the vertical flux to the deepsea floor, and their consumption could lead to the pres- 
ence of 20:1 isomers in Travisia sp. and Paradiopatra sp. While faecal pellets probably have low FA contents, copepod body parts could contain higher levels of 20:1 isomers.

The ratio of 18:1 $\omega 9 / 18: 1 \omega 7$ is often used as an indicator of carnivory in marine animals. Many animals can synthesize 18:169 from its saturated precursor 18:0,

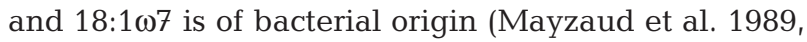
Nichols et al. 1991) or synthesized by chain elongation of 16:1 $1 \omega 7$, which is algal or bacterial in origin (Graeve

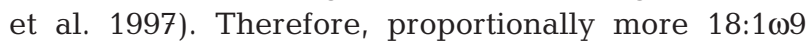
indicates carnivory, whereas more 18:107 indicates herbivory or detritivory (Graeve et al. 1997, Buhring \& Christiansen 2001). Although 18:303 co-elutes with $18: 1 \omega 9$ on the GC column, it is only a very minor component in this study. The polychaetes had ratios of 18:1 $\omega 9 / 18: 1 \omega 7$ between 0.8 and 1.0 (Table 3 ), suggesting that they consume more detritus than the other taxa examined in the present study. The benthic polychaete Onuphis conchylega, in the same family as Paradiopatra sp., had a very low 18:1 $\omega 9 / 18: 1 \omega 7$ ratio of 0.24 (Graeve et al. 1997), suggesting that Paradiopatra sp. relies more on predation than the shallow living O. conchylega.

\section{Cnidaria}

The lipid biomarkers for the anemone Bathyphellia australis suggest a mixed diet of phytodetritus and animal material similar to that of the polychaetes. B. australis is an anemone found almost exclusively attached to manganese nodules (Lauerman et al. 1996). Based on isotopic evidence and ST profiles, this animal apparently feeds on some resuspended phytodetritus and also on zooplankton (Drazen et al. 2008a). Its sessile lifestyle is similar to that of the polychaete Paradiopatra sp., and indeed it has similar levels of storage lipid, suggesting a somewhat sporadic food supply. In addition, the ST profile of $B$. australis was similar to that of Paradiopatra sp., reflecting a mix of phytodetrital and animal material in their diets, despite different modes of feeding. Long-chain MUFA such as 20:1 were abundant in $B$. australis, which, as discussed above, may represent consumption of copepods. The 18:1 $\omega 9 / 18: 1 \omega 7$ ratio for $B$. australis (1.7, Table 3) indicates a relatively more carnivorous diet than the polychaetes.

\section{Crustacea}

Unlike the other animals in this study, the caridean shrimp and the 2 lysianassid amphipods contained $>50 \%$ storage lipids (TAG $+\mathrm{WE}$ ), with the latter hav- ing a high lipid content. It is possible that the high levels of neutral lipid found in these crustaceans are associated with the hepatopancreas. There are numerous reports of TAG-rich amphipods from the continental shelf (Graeve et al. 1997) to the abyss (Buhring \& Christiansen 2001). Scavenging lysianassids are well known for their ability to gorge themselves and survive for months between feeding bouts (Hargrave et al. 1994). Clearly, the ability to store energy in the form of lipids is a benefit if feeding is sporadic. The foraging habits of the shrimp are unknown, but based on isotopic evidence it is a high trophic level predator (Drazen et al. 2008a). Munidopsis sp. did not have large amounts of lipid or high proportions of storage lipids. It is difficult to compare lipids and FA of Munidopsis sp. with the other crustaceans, since only the muscle tissues of this crab were analysed. Whole M. subsquamosa from a deep-sea hydrothermal vent system also had low amounts of lipid (10 $\mathrm{mg} \mathrm{g}^{-1}$ wet weight) and a similar proportion of $\mathrm{ST}_{\text {; }}$ however, its proportion of TAG (53\%) (Phleger et al. 2005a) was much larger than observed in the abyssal taxa examined in this study.

Of the crustaceans, only Munidopsis sp. had any phytosterols (1\%), suggesting that diets of most taxa almost entirely consisted of animal matter. Since crustaceans can convert phytosterol to cholesterol, it is also possible that phytosterols in the diet were more rapidly converted to cholesterol than in the other invertebrates. Amphipods are well known scavengers, but a diet study employing DNA-based markers suggested that hadal species are facultative scavengers and do consume some detritus (Blankenship \& Levin 2007). The absence of phytosterols in amphipods does not suggest that this is the case at Stn M. Bathyal galatheids eat a mixed diet of infauna and detritus (Cartes et al. 2007) and sometimes carrion (Kemp et al. 2006), reflecting an opportunistic foraging strategy. Even a galatheid from a hydrothermal vent area, Munidopsis subsquamosa, which is a predator on benthic invertebrates, had small amounts of the phytosterol desmosterol, suggesting phytodetrital inputs to its diet (Phleger et al. 2005a).

The lysianassid amphipods and the caridean shrimp had low proportions of PUFA and high MUFA (Table 1). The only other study of abyssal amphipods yielded almost identical results (Bühring \& Christiansen 2001). The FA profiles probably reflect the high TAG content of these animals. However, Nelson et al. (2001) found no correlation between lipid content and MUFA levels in Antarctic amphipod species. As discussed for the polychaetes, the high levels of 20:1 and 22:1 in the shrimp may reflect feeding on copepods. The relatively low amounts of these long-chain 
MUFA in the crab and amphipods suggested a different feeding mode such as the consumption of carrion and other large organisms (Hargrave et al. 1994, Kemp et al. 2006).

High levels of the PUFA EPA and DHA in Munidopsis sp. contributed to its separation on PC2 of the PCA analysis (Fig. 2). EPA, DHA and total PUFA levels were relatively high compared to $M$. subsquamosa from a hydrothermal vent system (Phleger et al. 2005a), which consumes a variety of benthic animals. The abyssal Munidopsis sp. probably consumes a diet rich in PUFA compared to the hydrothermal vent $M$. subsquamosa, indicating a greater reliance on photosynthetically derived material.

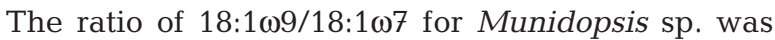
1.0 (Table 1), similar to those for predatory decapods, known to be macrophagous, feeding on small benthic or benthopelagic organisms (Graeve et al. 1997). The ratio for Munidopsis sp. is less than the ratio for the hydrothermal vent $M$. subsquamosa (1.4, Phleger et al. 2005a), which with Munidopsis sp.'s higher PUFA suggests a greater reliance on detritus in the abyssal species.

The caridean shrimp had a 18:1 $\omega 9 / 18: 1 \omega 7$ ratio of 1.6 in support of the other data indicating a carnivorous diet. The 2 lysianassid amphipods had very high levels of $18: 1 \omega 9$ and $18: 1 \omega 9 / 18: 1 \omega 7$ ratios of 8.4 and 9.4, which clearly distinguished them from the other taxa examined (Fig. 2). Their 18:1 $\omega 9 / 18: 1 \omega 7$ ratios are very similar to those of other abyssal lysianassids and abyssal benthopelagic copepods from the North Atlantic (Buhring \& Christiansen 2001), and such high ratios probably reflect a dominance of carrion in their diets. Arctic benthic amphipods from the continental shelf had lower ratios of 3.3 to 3.6 (Graeve et al. 1997). The variation in this ratio between these animals likely reflects dietary differences, including the relative importance of scavenging on the carcasses of large animals.

\section{Lipid metabolism}

Munidopsis sp. had very low levels of NMI $(0.3 \%)$ compared to $M$. subsquamosa (4\%) from hydrothermal vents (Phleger et al. 2005a). The NMI 20:2 is formed by animals that chain elongate and desaturate 18:1 107 which is derived from bacteria. The lack of NMI in Munidopsis sp. indicates that bacteria are not a major part of the diet. Combined with higher DHA levels (12\%), it also indicates that chain elongation and desaturation are not occurring to any extent. The higher DHA levels, if arising from other dietary sources along with EPA, likely inhibit the chain elongation and desaturation of C18 FA (Pond et al. 2002).
The 2 lysianassid amphipods also had very low NMI (0.1 to $0.2 \%$ ) with moderate levels of DHA and EPA (Table 3). Total NMI in the shrimp were $2 \%$ and DHA $3 \%$. These levels of NMI and moderate levels of vaccenic acid $(18: 1 \omega 7,9 \%)$ may indicate that chain elongation and desaturation of C18 FA is occurring in this crustacean. The polychaetes had much more NMI (8 to $13 \%$ ), relatively low DHA levels, and 6 to $9 \%$ 18:1 107 , suggesting that chain elongation and desaturation might be occurring in these animals as well.

\section{SUMMARY}

These signature lipid profiles provide insights into the trophodynamics of abyssal communities. The FA profiles are the first for abyssal animals in the Pacific. Lipid stores of scavenging lysianassid amphipods and an unidentified caridean shrimp are very high and suggest sporadic feeding. Phytosterols were present in the anemone Munidopsis sp. and the polychaetes, providing evidence for the consumption of phytodetritus albeit as a small component of the diet. These data were corroborated by an analysis of essential

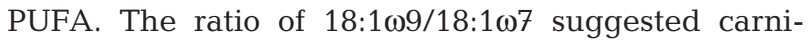
vory as the predominant mode of foraging. The high 18:1 $\omega 9 / 18: 1 \omega 7$ ratios in shrimp and amphipods and the absence of phytosterols suggests diets almost exclusively of animal material. Some distinct differences in the FA composition of the examined taxa allowed for their separation, indicating that FA profiles will be useful in future biomarker approaches to deep-sea food web studies. The abyssal food web is supported by a flux of phytodetritus from the euphotic zone and the abundance of some populations fluctuate inter-annually in concert with changes in this food supply (Ruhl \& Smith 2004). Carefully establishing cause and effect requires well-described food webs. The present results assist in achieving that goal. However, in some systems, seasonal and sometimes inter-annual variations in FA composition occur (Nelson et al. 2001, Hudson et al. 2004), which may further influence trophic connections. Future research in the Pacific should investigate to which extent such temporal variations exist.

Acknowledgements. We thank K. L. Smith for the opportunity to participate on cruise Pulse 49 aboard the RV 'Atlantis' to Stn $M$ and to the cruise participants for their assistance with sample collection and processing. D. Holdsworth managed the CSIRO GC-MS facility. This paper was improved by the comments of 3 anonymous reviewers. This research was supported by funding from the School of Ocean and Earth Science and Technology, University of Hawaii, to J.C.D. 


\section{LITERATURE CITED}

Ackman RG, Eaton CA (1966) Lipids of the fin whale (Balaenoptera physalus) from North Atlantic waters. III. Occurrence of eicosenoic and docosenoic fatty acids in the zooplankter Meganyctiphanes norvegica (M. sars) and their effect on whale oil composition. Can J Biochem 44: 1561-1566

Best NJ, Bradshaw CJA, Hindell MA, Nichols PD (2003) Vertical stratification of fatty acids in the blubber of southern elephant seals (Mirounga leonina): implications for diet analysis. Comp Biochem Physiol B 134:253-263

Billett DSM (1991) Deep-sea holothurians. Oceanogr Mar Biol Annu Rev 29:259-317

Blankenship LE, Levin LA (2007) Extreme food webs: foraging strategies and diets of scavenging amphipods from the ocean's deepest 5 kilometers. Limnol Oceanogr 52: 1685-1697

Bligh EG, Dyer WJ (1959) A rapid method of total lipid extraction and purification. Can J Biochem Physiol 37:911-917

Brown MR, Dunstan GA, Jeffrey SW, Volkman JK, Barrett SM, LeRoi JM (1993) The influence of irradiance on the biochemical composition of the pyrmnesiophyte Isochrsis sp. (clone t-iso). J Phycol 29:601-612

Bühring SI, Christiansen B (2001) Lipids in selected abyssal benthopelagic animals: links to the epipelagic zone? Prog Oceanogr 50:369-382

Cartes JE, Huguet C, Parra S, Sanchez F (2007) Trophic relationships in deep-water decapods of Le Danois bank (Cantabrian Sea, NE Atlantic): trends related with depth and seasonal changes in food quality and availability. Deep-Sea Res I 54:1091-1110

Christie WW (1982) Lipid analysis. Pergamon Press, Oxford

Colaço A, Desbruyeres D, Guezennec DJ (2007) Polar lipid fatty acids as indicators of trophic associations in a deepsea vent system community. PSZN I: Mar Ecol 28:15-24

Drazen JC, Popp BN, Choy CA, Clemente T, De Forest LG, Smith KL (2008a) Bypassing the abyssal benthic food-web: macrourid diet in the eastern North Pacific inferred from stomach content and stable isotopes analyses. Limnol Oceanogr 53:2644-2654

Drazen JC, Phleger CF, Guest MA, Nichols PD (2008b) Lipid, sterols and fatty acid composition of abyssal holothurians and ophiuroids from the north-east Pacific Ocean: food web implications. Comp Biochem Physiol B 151:79-87

Fauchald K, Jumars PA (1979) The diet of worms: a study of polychaete feeding guilds. Oceanogr Mar Biol Annu Rev 17:193-284

Goad LJ (1978) The sterols of marine invertebrates: composition, biosynthesis, and metabolites. In: Scheuer PJ (ed) Marine natural products, chemical and biological perspectives. Academic Press, New York, p 75-172

> Graeve M, Kattner G, Piepenburg D (1997) Lipids in Arctic benthos: Does the fatty acid and alcohol composition reflect feeding and trophic interactions? Polar Biol 18:53-61

Graeve M, Kattner G, Wiencke C, Karsten U (2002) Fatty acid composition of Arctic and Antarctic macroalgae: indicator of phylogenetic and trophic relationships. Mar Ecol Prog Ser 231:67-74

- Hargrave BT, Prouse NJ, Phillips GA, Cranford PJ (1994) Meal size and sustenance time in the deep-sea amphipod Eurythenes gryllus collected from the Arctic Ocean. DeepSea Res I 41:1489-1508

> Hudson IR, Pond DW, Billett DSM, Tyler PA, Lampitt RS, Wolff GA (2004) Temporal variations in fatty acid composition of deep-sea holothurians: evidence of benthopelagic coupling. Mar Ecol Prog Ser 281:109-120
Judd JR (2001) The physiological ecology of digestion in Arenicola brasiliensis, a deposit-feeding polychaete (Annelida). $\mathrm{PhD}$ dissertation, University of California Berkeley, CA

> Kemp KM, Jamieson AJ, Bagley PM, McGrath H, Bailey DM, Collins MA, Priede IG (2006) Consumption of large bathyal food fall, a six month study in the NE Atlantic. Mar Ecol Prog Ser 310:65-76

> Lauerman LML, Kaufmann RS, Smith KL Jr (1996) Distribution and abundance of epibenthic megafauna at a long time-series station in the abyssal Northeast Pacific. DeepSea Res I 43:1075-1103

Lee RF, Patton JS (1989) Alcohol and waxes. In: Ackman RG (ed) Marine biogenic lipids, fats and oils. CRC Press, Boca Raton, FL, p 73-102

Martin B, Christiansen B (1997) Diets and standing stocks of benthopelagic fishes at two bathymetrically different midoceanic localities in the Northeast Atlantic. Deep-Sea Res I 44:541-558

Mayzaud P, Chanut JP, Ackman RG (1989) Seasonal changes of the biochemical composition of marine particulate matter with special reference to fatty acids and sterols. Mar Ecol Prog Ser 56:189-204

> Nelson MM, Mooney BD, Nichols PD, Phleger CF (2001) Lipids of Antarctic Ocean amphipods: food chain interactions and the occurrence of novel biomarkers. Mar Chem 73:53-64

Nelson MM, Olley J, Crear BJ, Lewis T, Nichols PD (2005) Comparison of wild and cultured adult southern rock lobster, Jasus edwardsii: growth, sensory analysis and oil composition. Food Aust 57:499-509

> Nichols PD, Palmissano AC, Smith GA, White DC (1986) Lipids of the Antarctic sea ice diatom Nitzschia cylindrus. Phytochemistry 25:1649-1653

Nichols PD, Skerrat JH, Davidson A, Burton H, McMeekin TA (1991) The lipid composition of cultured Phaeocystis poucheti: signatures for food-web biogeochemical and environmental studies in Antarctica and the Southern Ocean. Phytochemistry 30:3209-3214

Nichols PD, Phillips K, Mooney B, Wilson G, Phleger CF (2007) Signature lipid and fatty acid profiling in food web studies. In: Furlani DM, Lyle J (eds) Cutting-edge technologies in fish and fisheries science Australian Society for Fish Biology workshop proceedings, Hobart, 28-31 August 2006

> Okamura N, Stoskopf M, Yamaguchi H, Kishimoto Y (1985) Lipid composition of the nervous system of earthworms (Lumbricus terrestris). J Neurochem 45:1875-1879

Phleger CF, Nichols PD, Virtue P (1998) Lipids and trophodynamics of Antarctic zooplankton. Comp Biochem Physiol 120B:311-323

Phleger CF, Nelson MA, Groce AK, Cary SC, Coyne KJ, Nichols PD (2005a) Lipid composition of deep-sea hydrothermal vent tubeworm Riftia pachyptila, crabs Munidopsis subsquamosa and Bythograea thermydron, mussels Bathymodiolus sp. and limpets Lepetodrilus spp. Comp Biochem Physiol B 141:196-210

> Phleger CF, Nelson MM, Groce AK, Carye SC, Coyne K, Gibson JAE, Nichols PD (2005b) Lipid biomarkers of deep-sea hydrothermal vent polychaetes-Alvinella pompejana, A. caudata, Paralvinella grasslei and Hesiolyra bergii. Deep-Sea Res I 52:2333-2352

> Pond DW, Allen CE, Bell MV, Dover CLV, Fallick AE, Dixon DR, Sargent JR (2002) Origins of long-chain polyunsaturated fatty acids in the hydrothermal vent worms Ridgea piscesae and Protis hydrothermica. Mar Ecol Prog Ser 225: 219-226

> Rozner S, Garti N (2006) The activity and absorption relation- 
ship of cholesterol and phytosterols. Coll Surf A 282-283: 435-456

Ruhl HA (2007) Abundance and size distribution dynamics of abyssal epibenthic megafauna in the northeast Pacific. Ecology 88:1250-1262

Ruhl HA, Smith KL Jr (2004) Shifts in deep-sea community structure linked to climate and food supply. Science 305: $513-515$

Sargent JR (1976) The structure, metabolism and function of lipids in marine organisms. In: Malins C, Sargent JR (eds) Biochemical and biophysical perspectives in marine biology, Vol 3. Academic Press, London, p 149-212

Sargent JR, Whittle JJ (1981) Lipids and hydrocarbons in the marine food web. In: Longhurst AR (ed) Analysis of marine ecosystems. Academic Press, London, p 491-553

Smith KL Jr, Druffel ERM (1998) Long time-series monitoring of an abyssal site in the NE Pacific: an introduction. DeepSea Res II 45:573-586

Editorial responsibility: Robert Feller, Columbia, South Carolina, USA
Trautwein EA, Duchateau GSMJE, Lin Y, Mel'nikov SM, Molhuizen HOF, Ntanios FY (2003) Proposed mechanisms of cholesterol-lowering action of plant sterols. Eur J Lipid Sci Technol 105:171-185

Volkman JK (1986) A review of sterol markers for marine and terrigenous organic matter. Org Geochem 9:83-99

Volkman JK, Nichols PD (1991) Applications of thin layer chromatography-flame ionization detection to the analysis of lipids and pollutants in marine and environmental samples. J Planar Chromat 4:19-26

Volkman JK, Jeffrey SW, Nichols PD, Rogers GI, Garland CD (1989) Fatty acid and lipid composition of 10 species of microalgae used in mariculture. J Exp Mar Biol Ecol 128: 219-240

Wakeham SG, Lee C, Farrington JW, Gagosian RB (1984) Biogeochemistry of particulate organic matter in the oceans: Results from sediment trap experiments. Deep-Sea Res A 31:509-528

Submitted: May 14, 2008; Accepted: August 22, 2008 Proofs received from author(s): November 22, 2008 